\title{
MJMR IMPACT OF COVID-19 PANDEMIC ON MENTAL AND EMOTIONAL WELLBEING AMONG CHILDREN: A SYSTEMATIC REVIEW
} \author{
Faridah binti Mohd Said ${ }^{5}$, Sevendor Khor@Bibi Florina Abdullah ${ }^{5}$ \\ ${ }^{1}$ Nursing Student at Lincoln University College, Malaysia \\ ${ }^{2}$ STIKes Murni Teguh Medan, 20371, Indonesia \\ ${ }^{3}$ STIKes Jenderal Achmad Yani Cimahi, 40633, Indonesia \\ ${ }^{4}$ STIKes Jenderal Achmad Yani Cimahi, 40633, Indonesia \\ ${ }^{5}$ Faculty of Nursing, Lincoln University College, Malaysia \\ *Corresponding Author's Email: dior.endlessbay@gmail.com
}

Dior Manta Tambunan ${ }^{1,2 *}$, Nunung Nurjanah ${ }^{3}$, Siti Dewi Rahmayanti ${ }^{3}$, Rahmi Imelisa ${ }^{4}$,

\begin{abstract}
Background: Coronavirus pandemic represents a huge threat and phenomenal risks on mental and emotional wellness among children. This systematic review expects to integrate academic research literature that provides details regarding the impact of COVID-19 on emotional wellbeing and mental status among children. Methods: A systematic research engine was escorted on PubMed, Proquest, ScienceDirect, and Google Scholar with keywords: Children, COVID-19, Mental Status, Psychological Status from December 2019 to 18 November 2020 following the PRISMA guidelines. Articles were chosen dependent on the predetermined eligibility criteria. The included articles to review used the Quality Assessment Tool Adapted from the National Institutes of Health (NIH). Results: A total of 17,059 records were identified using the keywords. After removal of duplicates and initial screening, seven articles met the inclusion criteria of COVID-19 influence on mental and emotional wellbeing among children. The research design was a longitudinal and cross-sectional online survey with the children age range was $3-18$ years old. Conclusions: COVID-19 Pandemic has a significant influence on mental and emotional wellbeing among children. Some children experienced depressive indication, difficulty concentrating, anxiety, touchy and easy to get irritated. Limitations: Online survey generalized the results, younger children might need assistance from parents during filling up the questionnaire, small sampling size.
\end{abstract}

Keywords: Children; COVID-19; Mental Status; Psychological Status

\section{INTRODUCTION}

Infectious illnesses stay perhaps the greatest danger to the wellbeing and prosperity of humankind. Since December 2019, novel COVID-19 contamination has spread quickly all over China and universally (Cao et al., 2020). There are more than 2.2 billion children on the planet who establish around $28 \%$ of the total populace. Those who matured between 10 to 19 years make up $16 \%$ of the total populace (UNICEF, 2019). During the most recent couple of months, children around the globe have encountered a significant interruption of children's regular day-to-day existences and daily schedules because of the COVID-19 pandemic.

There is a lack of persuasive evidence of the influence of the Covid-19 pandemic on mental and psychological status among children. Routines, social connections, and companionships are among the main elements liable for children's normal emotional wellbeing and development. Being stayed at home or social distancing frequently breaks children's standard schedules and can make the ongoing difficult condition far more challenging in long term adverse consequences for children (Lee, 2020; Liu et al., 2020; Shen et al., 2020; \& Imran et al., 2020). The objective of this systematic review expects to integrate academic research literature that provides details regarding the impact of COVID-19 on emotional wellbeing and mental status among children.

\section{METHODOLOGY}

\section{Search Strategy}

A systematic research engine was escorted on PubMed, 
Proquest, ScienceDirect, and Google Scholar from December 2019 to November 2020 following the PRISMA flow diagram as seen in Figure 1. It was searched using the following keywords: (Children) AND (COVID-19) and (Mental Status) AND (Psychological Status). A total of 17,059 records were identified using the keywords from December 2019 to November 2020. Records were $\mathrm{n}=1,538$ after removing irrelevant records $(n=15,521)$. After 603 duplicates records were removed and 935 records screened for titles and abstract screening and full-text articles assessed for eligibility were $n=91$ only after tracing out records that did not match eligibility were $n=844$. However, 84 full-text articles were excluded for reasons: healthcare population, mental disorder, review paper, and population on quarantine. Finally, this review included 7 studies in synthesizing.

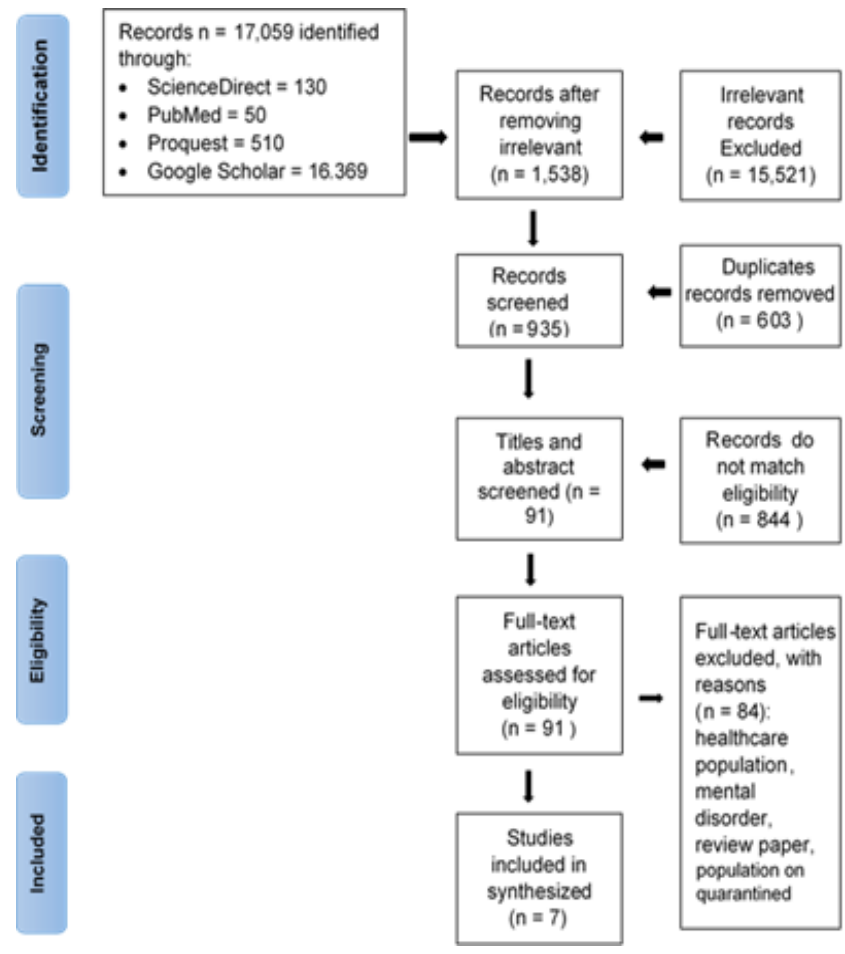

Figure 1: Preferred Reporting Items for Systematic Reviews and Meta-Analyses (PRISMA) Study Selection flow Diagram. (For Interpretation of the References to Color in this figure Legend, the Reader is Referred to the Web Version of this Article.)

\section{Study Selection and Eligibility Criteria}

Titles and abstracts of every distribution were screened for pertinence. Full-text articles were examined for qualification after the underlying screening. Studies were eligible for:

\section{Inclussion Criteria were}

1. Full-text and open access articles

2. Range from December 2019 to November 2020

3. English-only articles

4. Flowed quantitative: cross-sectional and longitudinal study design

5. Studies assessed the mental and psychological wellbeing among children during the COVID-19 pandemic.

6. Children's age $<18$ years.

\section{Exclusions Criteria were}

1. Studies that were not assessed for mental and psychological wellbeing effect on COVID-19 pandemic among children.

2. Unreliable data collections, duplicate, and overlapping articles.

3. Review articles, not fully accessible research articles, book subsidiaries, conference papers, abstract-only articles, and animals related studies.

\section{Data Extraction}

Data extraction form was used to include relevant data: (1) Thematic area, (2) Lead author/year/country, (3) Study design, (4) Sample size, (5) Sample characteristics, (6) Assessment tool, (7) Summary of results, and (8) Limitation.

\section{Quality Assessment Tool}

The included articles to review used the Quality Assessment Tool Adapted from the National Institutes of Health (NIH) in Table 1. The quality assessment was conducted by two authors (SR) and the overall quality of the included studies is Rated fairly, with a total score of 45 out of 14 questions for 7 articles. There were 5 questions with fully (7 articles) answered Yes, 2 questions were answered yes with 4 articles, and 1 question was answered yes with 1 only article. While the rest of the question was answered with No, CD, NR, and NA with scored with Nol. 
Table 1: Quality Assessment Tool Adapted from National Institutes of Health (NIH)

\begin{tabular}{|c|c|c|c|}
\hline SL & CRITERIA & Yes & \begin{tabular}{l|l} 
No & Other (CD, NR, NA) \\
\end{tabular} \\
\hline 1 & $\begin{array}{l}\text { Were the research question or objective } \\
\text { in this paper clearly stated? }\end{array}$ & Yes: 7 (Value:7) & \\
\hline 2 & $\begin{array}{l}\text { Were the study population clearly } \\
\text { specified and defined? }\end{array}$ & Yes: 7 (Value:7) & \\
\hline 3 & $\begin{array}{l}\text { Were the participation rate of eligible } \\
\text { persons at least } 50 \% \text { ? }\end{array}$ & Yes: 7 (Value:7) & \\
\hline 4 & $\begin{array}{l}\text { Were all the subjects selected or } \\
\text { recruited from the same or similar } \\
\text { populations (including the same time } \\
\text { period)? Were inclusion and exclusion } \\
\text { criteria for being in the study } \\
\text { prespecified and applied uniformly to } \\
\text { all participants? }\end{array}$ & $\begin{array}{l}\text { Yes: } 4 \text { (Value:4) } \\
\text { No: } 1 \text { (Value:0) } \\
\text { CD: } 2 \text { (Value:0) }\end{array}$ & \\
\hline 5 & $\begin{array}{l}\text { Were a sample size justification, power } \\
\text { description, or variance and effect } \\
\text { estimates provided? }\end{array}$ & $\begin{array}{l}\text { Yes: } 2 \text { (Value:2), No: } 3 \text { (Value:0) } \\
\text { CD: } 2 \text { (Value:0) }\end{array}$ & \\
\hline 6 & $\begin{array}{l}\text { For the analyses in this paper, were the } \\
\text { exposure(s) of interest measured prior } \\
\text { to the outcome(s) being measured? }\end{array}$ & $\begin{array}{l}\text { Yes: } 0 \text { (Value:0), No: } 2 \text { (Value:0) } \\
\text { CD: } 3 \text { \& NA: } 2 \text { (Value:0) }\end{array}$ & \\
\hline 7 & $\begin{array}{l}\text { Were the timeframe sufficient so that } \\
\text { one could reasonably expect to see an } \\
\text { association between exposure and } \\
\text { outcome if it existed? }\end{array}$ & $\begin{array}{l}\text { Yes: } 4 \text { (Value:4), No: } 0 \text { (Value:0) } \\
\text { CD: } 3 \text { (Value:0) }\end{array}$ & \\
\hline 8 & $\begin{array}{l}\text { For exposures that can vary in amount } \\
\text { or level, did the study examine } \\
\text { different levels of the exposure as } \\
\text { related to the outcome (e.g., categories } \\
\text { of exposure, or exposure measured as } \\
\text { continuous variable)? }\end{array}$ & Yes: 0 (Value: 0), No: 7 (Value:0) & \\
\hline 9 & $\begin{array}{l}\text { Were the exposure measures } \\
\text { (independent variables) clearly } \\
\text { defined, valid, reliable, and } \\
\text { implemented consistently across all } \\
\text { study participants? }\end{array}$ & Yes: 7 (Value:7), No: 0 (Value:0) & \\
\hline 10 & $\begin{array}{l}\text { Were the exposure(s) assessed more } \\
\text { than once over time? }\end{array}$ & Yes: 0 (Value:0), No: 7 (Value:0) & \\
\hline 11 & $\begin{array}{l}\text { Were the outcome measures } \\
\text { (dependent variables) clear ly defined, } \\
\text { valid, reliable, and implemented } \\
\text { consistently across all study } \\
\text { participants? }\end{array}$ & Yes: 7 (Value:7), No: 0 (Value:0) & \\
\hline 12 & $\begin{array}{l}\text { Were the outcome assessors blinded to } \\
\text { the exposure status of participants? }\end{array}$ & $\begin{array}{l}\text { Yes: } 0 \text { (Value:0), No: } 0 \text { (Value:0) } \\
\text { CD: } 7 \text { (Value:0) }\end{array}$ & \\
\hline 13 & $\begin{array}{l}\text { Were loss to follow -up after baseline } \\
20 \% \text { or less? }\end{array}$ & $\begin{array}{l}\text { Yes: } 0 \text { (Value:0), No: } 0 \text { (Value:0) } \\
\text { NR: } 7 \text { (Value:0) }\end{array}$ & \\
\hline 14 & $\begin{array}{l}\text { Were key potential confounding } \\
\text { variables measured and adjusted } \\
\text { statistically for their impact on the } \\
\text { relationship between exposure(s) and } \\
\text { outcome(s)? }\end{array}$ & $\begin{array}{l}\text { Yes: } 0 \text { (Value:0), No: } 0 \text { (Value:0) } \\
\text { NR: } 7 \text { (Value:0) }\end{array}$ & \\
\hline
\end{tabular}

Note: Exposure measures indicate independent variables.

${ }^{*} C D=$ cannot determine $; A=$ not applicable $; N R=$ not reported 


\section{RESULTS AND DISCUSSION}

This review investigated the mental and emotional wellbeing or status of children during the COVID-19 pandemic. We recognized a surprising deficiency of information on the impact of the COVID-19 Pandemic on children during disease outbreaks. It was astounding that the dominant part of studies we found, were for the quickly arising COVID-19 Pandemic as opposed to past SARS or MERS flare-ups (Orgilés et al., 2020; Pisano, Galimi \& Cerniglia, 2020).

\section{Study Characteristics}

Study characteristics and primary study findings are summarized in Table 2. The sampling size of the 7 studies ranged from 190 to 3,613 respondents, with a total of 7,813 respondents. A majority of studies where children as participants were between 3 - 18 years old. All studies followed a quantitative with cross-sectional and longitudinal online study design. The 7 studies were conducted in 6 different countries and each study including Spain, Italy, Bangladesh, Greece, South Western Ontario, and 2 studies was in China. The main results picked in the included studies varied across studies. Thematic of the studies included thematic on lockdown and mental health $(\mathrm{n}=2)$, psychological impact/effect $(\mathrm{n}=2)$, mental health impact $(\mathrm{n}=2)$, and mental health investigation $(\mathrm{n}=1)$.

Table 2: Articles Influence COVID-19 Pandemic on Mental and Emotional Wellbeing among Children

\begin{tabular}{|c|c|c|c|c|c|c|c|}
\hline No & $\begin{array}{l}\text { Themati } \\
\text { c Area }\end{array}$ & $\begin{array}{l}\text { Lead Author, } \\
\text { Year } \\
\text { (Country) }\end{array}$ & $\begin{array}{l}\text { Study Design } \\
\text { and Sample } \\
\text { Size }(n=)\end{array}$ & $\begin{array}{l}\text { Sample } \\
\text { Characteristics }\end{array}$ & $\begin{array}{l}\text { Assessment } \\
\text { Tool }\end{array}$ & Summary of Results & Limitations \\
\hline 1 & $\begin{array}{l}\text { Lockdow } \\
\mathrm{n} \text { and } \\
\text { mental } \\
\text { health }\end{array}$ & $\begin{array}{l}\text { Ezpeleta et al ., } \\
2020 \\
\text { (Spain) }\end{array}$ & $\begin{array}{l}\text { Longitudinal } \\
\text { online } \\
\text { Study } \\
\text { (226 parents) }\end{array}$ & $\begin{array}{l}\text { Age range: N/A; } \\
\text { Mean age: } 13.9 ; \\
\text { SD: } 0.28 ; \\
\text { Children Sex } \\
(\mathrm{f} / \mathrm{m}): 117 / 109\end{array}$ & SDQ & $\begin{array}{l}\text { Worse adolescents' } \\
\text { psychological } \\
\text { wellbeing during } \\
\text { COVID-19 lockdown } \\
\text { was related to } \\
\text { undesirable exercises, } \\
\text { worse the associations } \\
\text { with others, and } \\
\text { useless nurturing style. }\end{array}$ & $\begin{array}{l}\text { Some respondents } \\
\text { were in the lower } \\
\text { financial levels, } \\
\text { so subsequently } \\
\text { the outcomes can't } \\
\text { be summed up to } \\
\text { the most hindered } \\
\text { gatherings. }\end{array}$ \\
\hline 2 & $\begin{array}{l}\text { Lockdow } \\
\mathrm{n} \text { and } \\
\text { mental } \\
\text { health }\end{array}$ & $\begin{array}{l}\text { Magklara et al., } \\
2020 \\
\text { (Greec }\end{array}$ & $\begin{array}{l}\text { Cross- } \\
\text { Sectional } \\
\text { online } \\
\text { Survey (1232) } \\
\text { parents }\end{array}$ & $\begin{array}{l}\text { Age range: }<18 ; \\
\text { Mean age: N/A; } \\
\%=<13 \text { years } \\
(70.4) \\
\%=\geq 13 \text { years } \\
(29.6) ; \\
\text { SD: N/A; } \\
\text { Children Sex } \\
(\mathrm{f} / \mathrm{m}): 593 / 676\end{array}$ & CRISIS & $\begin{array}{l}\text { Roughly } 35.1 \% \text { of } \\
\text { caregivers reported } \\
\text { that the mental } \\
\text { wellbeing of their } \\
\text { children was } \\
\text { impressively } \\
\text { influenced. } \\
\text { The main concern was } \\
\text { social detachment. }\end{array}$ & $\begin{array}{l}\text { Convenience } \\
\text { online samples } \\
\text { cannot repr esent } \\
\text { the population. } \\
\text { Used Parental } \\
\text { reports. } \\
\text { Restricted } \\
\text { occasions to } \\
\text { utilize more } \\
\text { emotional } \\
\text { proportions of } \\
\text { children's } \\
\text { qualities and } \\
\text { troubles. } \\
\text { Online surveys } \\
\text { introduced huge } \\
\text { challenges for the } \\
\text { utilization of } \\
\text { children as } \\
\text { respondents. }\end{array}$ \\
\hline 3 & $\begin{array}{l}\text { Psycholo } \\
\text { gical } \\
\text { Impact }\end{array}$ & $\begin{array}{l}\text { Zhang et al ., } \\
2020 \\
\text { (China) }\end{array}$ & $\begin{array}{l}\text { Cross- } \\
\text { Sectional } \\
\text { online } \\
\text { Survey (1025 } \\
\text { school } \\
\text { students) }\end{array}$ & $\begin{array}{l}\text { Age range: N/A; } \\
\text { Mean age: } \\
15.56 ; \\
\text { SD: } 1.89 ; \\
\text { Children Sex } \\
\text { (f/m): } 497 / 528\end{array}$ & $\begin{array}{l}\text { BRS; CSQ; } \\
\text { IES; DASS } \\
21\end{array}$ & $\begin{array}{l}\text { More than one -fifth of } \\
\text { respondents' emotional } \\
\text { wellbeing was } \\
\text { influenced. } \\
\text { These results can be } \\
\text { utilized to formulate } \\
\text { psychological } \\
\text { management to } \\
\text { improve emotional } \\
\text { wellness. }\end{array}$ & $\begin{array}{l}\text { Cross-sectional } \\
\text { design blocked } \\
\text { the capacity to } \\
\text { build up a causal } \\
\text { connection. } \\
\text { Depend on } \\
\text { respondents' self - } \\
\text { selection and may } \\
\text { prompt bias, } \\
\text { especially when }\end{array}$ \\
\hline
\end{tabular}




\begin{tabular}{|c|c|c|c|c|c|c|c|}
\hline & & & & & & $\begin{array}{l}\text { Recommended that } \\
\text { strength and positive } \\
\text { adapting lead to better } \\
\text { mental and emotional } \\
\text { wellbeing status. }\end{array}$ & $\begin{array}{l}\text { the reaction rate is } \\
\text { low. } \\
\text { Ideas were } \\
\text { surveyed without } \\
\text { help from anyone } \\
\text { else report. } \\
\text { Suggestions on } \\
\text { next study using a } \\
\text { multimethod } \\
\text { approach for } \\
\text { evaluation. }\end{array}$ \\
\hline 4 & $\begin{array}{l}\text { Mental } \\
\text { health } \\
\text { impact }\end{array}$ & $\begin{array}{l}\text { Yeasmin et al., } \\
2020 . \\
\text { (Bangladesh) }\end{array}$ & $\begin{array}{l}\text { Cross- } \\
\text { sectional } \\
\text { online } \\
\text { Study (384) } \\
\text { parents }\end{array}$ & $\begin{array}{l}\text { Age range: } 5-15 ; \\
\text { Mean age: N/A; } \\
\text { SD: N/A; } \\
\text { Children Sex } \\
(\mathrm{f} / \mathrm{m}) \text { : N/A }\end{array}$ & $\begin{array}{l}\text { RCADS; } \\
\text { MDD; GAD; } \\
\text { CBCL }\end{array}$ & $\begin{array}{l}\text { Exhibit that huge } \\
\text { extents of children are } \\
\text { experiencing } \\
\text { psychological } \\
\text { wellbeing disruption in } \\
\text { Bangladesh during the } \\
\text { lockdown period. } \\
\text { Execution of legitimate } \\
\text { mental management } \\
\text { strategies and parents' } \\
\text { education, looking } \\
\text { after children } \\
\text { appropriately, and } \\
\text { adaptability of parents } \\
\text { may help in improving } \\
\text { the wellbeing status of } \\
\text { children. }\end{array}$ & $\begin{array}{l}\text { Self-announcing } \\
\text { has certain } \\
\text { constraints } \\
\text { compared with } \\
\text { direct face contact } \\
\text { interviews. } \\
\text { This investigation } \\
\text { didn't follow the } \\
\text { viability of mental } \\
\text { services as cross - } \\
\text { sectional } \\
\text { research. } \\
\text { The bigger } \\
\text { sample size for } \\
\text { outcomes } \\
\text { validation. }\end{array}$ \\
\hline 4 & $\begin{array}{l}\text { Mental } \\
\text { health } \\
\text { impact }\end{array}$ & $\begin{array}{l}\text { Yeasmin et al., } \\
2020 . \\
\text { (Bangladesh) }\end{array}$ & $\begin{array}{l}\text { Cross- } \\
\text { sectional } \\
\text { online } \\
\text { Study (384) } \\
\text { parents }\end{array}$ & $\begin{array}{l}\text { Age range: } 5-15 ; \\
\text { Mean age: N/A; } \\
\text { SD: N/A; } \\
\text { Children Sex } \\
(\mathrm{f} / \mathrm{m}) \text { : N/A }\end{array}$ & $\begin{array}{l}\text { RCADS; } \\
\text { MDD; GAD; } \\
\text { CBCL }\end{array}$ & $\begin{array}{l}\text { Exhibit that huge } \\
\text { extents of children are } \\
\text { experiencing } \\
\text { psychological } \\
\text { wellbeing disruption in } \\
\text { Bangladesh during the } \\
\text { lockdown period. } \\
\text { Execution of legitimate } \\
\text { mental management } \\
\text { strategies and parents' } \\
\text { education, looking } \\
\text { after children } \\
\text { appropriately, and } \\
\text { adaptability of parents } \\
\text { may help in improving } \\
\text { the wellbeing status of } \\
\text { children. }\end{array}$ & $\begin{array}{l}\text { Self-announcing } \\
\text { has certain } \\
\text { constraints } \\
\text { compared with } \\
\text { direct face contact } \\
\text { interviews. } \\
\text { This investigation } \\
\text { didn't follow the } \\
\text { viability of mental } \\
\text { services as cross - } \\
\text { sectional } \\
\text { research. } \\
\text { The bigger } \\
\text { sample size for } \\
\text { outcomes } \\
\text { validation. }\end{array}$ \\
\hline 5 & $\begin{array}{l}\text { Mental } \\
\text { health } \\
\text { impact }\end{array}$ & $\begin{array}{l}\text { Mactavish et } \\
\text { al., 2020 } \\
\text { (South Western } \\
\text { Ontario) }\end{array}$ & $\begin{array}{l}\text { Longitudinal } \\
\text { online } \\
\text { Study (190 } \\
\text { parents) }\end{array}$ & $\begin{array}{l}\text { Age range: } \\
8-13 \text {; } \\
\text { Mean age: } 10.83 \text {; } \\
\text { SD: } 1.45 ; \\
\text { Children Sex } \\
\text { (f/m): } 94 / 96\end{array}$ & $\begin{array}{l}\text { SCARED; } \\
\text { SMFQ; ARI; } \\
\text { CPSS-5; } \\
\text { CRISIS }\end{array}$ & $\begin{array}{l}\text { It distinguishes } \\
\text { powerful, expansive } \\
\text { mental distress after } \\
\text { the COVID } \\
\text { pandemic. } \\
\text { Records wide intense } \\
\text { effect on the mental } \\
\text { wellbeing of children } \\
\text { since that it needs } \\
\text { expansive } \\
\text { psychosocial supports } \\
\text { and assets to assist } \\
\text { children with } \\
\text { recuperating from the } \\
\text { COVID-19 pandemic. }\end{array}$ & $\begin{array}{l}\text { Clinical } \\
\text { evaluation is } \\
\text { greatly subjected } \\
\text { to children and } \\
\text { parent reports of } \\
\text { manifestations } \\
\text { instead of } \\
\text { clinician- } \\
\text { surveyed } \\
\text { psychiatric or } \\
\text { mental } \\
\text { judgments. } \\
\text { Restrictions on } \\
\text { respondent } \\
\text { burden while } \\
\text { gathering }\end{array}$ \\
\hline
\end{tabular}




\begin{tabular}{|c|c|c|c|c|c|c|c|}
\hline & & & & & & & $\begin{array}{l}\text { information from } \\
\text { both children an d } \\
\text { caregivers. } \\
\text { Restricted to } \\
\text { cross-sectional } \\
\text { appraisal at } \\
\text { standard. } \\
\text { Scores were } \\
\text { analyzed against } \\
\text { huge samples } \\
\text { from research } \\
\text { preceding the } \\
\text { pandemic which } \\
\text { socioeconomics } \\
\text { was not } \\
\text { indistinguishable } \\
\text { from those of the } \\
\text { current } \\
\text { investigation. }\end{array}$ \\
\hline 6 & $\begin{array}{l}\text { Mental } \\
\text { health } \\
\text { investiga } \\
\text { tion }\end{array}$ & $\begin{array}{l}\text { Duan et al., } \\
2020 \\
\text { (China) }\end{array}$ & $\begin{array}{l}\text { Cross- } \\
\text { sectional } \\
\text { online } \\
\text { Study (3613 } \\
\text { children) }\end{array}$ & $\begin{array}{l}\text { Age range: } 7-8 ; \\
\text { Mean age: NA; } \\
\%=7-12(9.94), \\
\%=13-18(90.06) ; \\
\text { SD: N/A; } \\
\text { Children Sex } \\
\text { (f/m): } 1801 / 1812\end{array}$ & $\begin{array}{l}\text { SCAS; CDI; } \\
\text { SV-SAS; } \\
\text { IAS; CSS }\end{array}$ & $\begin{array}{l}\text { Demonstrate that the } \\
\text { COVID- } 19 \text { episode has } \\
\text { had a huge } \\
\text { psychosocial sway on } \\
\text { children. } \\
\text { The anxiety rate } \\
(22.28 \%) \text { of } \\
\text { respondents were in the } \\
\text { misery of depressive } \\
\text { indications. }\end{array}$ & $\begin{array}{l}\text { Sampling size } \\
\text { was moderately } \\
\text { little in the area } \\
\text { which influenced } \\
\text { relevance and } \\
\text { speculation of the } \\
\text { outcomes. } \\
\text { Children might be } \\
\text { affected by the } \\
\text { level of } \\
\text { comprehension } \\
\text { and collaboration } \\
\text { during filling up } \\
\text { the } \\
\text { questionnaires, } \\
\text { particularly } \\
\text { younger children } \\
\text { who need the } \\
\text { assistance of their } \\
\text { gatekeepers. }\end{array}$ \\
\hline 7 & $\begin{array}{l}\text { Psycholo } \\
\text { gical } \\
\text { effect }\end{array}$ & $\begin{array}{l}\text { Orgilés et al., } \\
2020 \\
\text { (Italy \& Spain) }\end{array}$ & $\begin{array}{l}\text { Online Survey } \\
(1143 \text { parents } \\
(62.3 \% \text { from } \\
\text { Spain \& } \\
37.7 \% \text { from } \\
\text { Italy) })\end{array}$ & $\begin{array}{l}\text { Age range: } 3-18 \text {; } \\
\text { Mean age: } 9.08 \text {; } \\
\text { SD: } 4.22 \text {; } \\
\text { Children Sex } \\
(\mathrm{f} / \mathrm{m}): 543 / 600\end{array}$ & $\begin{array}{l}\text { Survey } \\
\text { develop-ment } \\
\text { Question- } \\
\text { naire }\end{array}$ & $\begin{array}{l}\text { Emotionally } \\
\text { substitution state and } \\
\text { conduct with } \\
\text { indications, for } \\
\text { example, trouble } \\
\text { concentrating ( } 77 \%) \text {, } \\
\text { fatigue, touchiness, } \\
\text { fretfulness, anxiety, } \\
\text { sentiments of } \\
\text { depression, being more } \\
\text { uncomfortable and } \\
\text { more stressed. About } \\
12 \% \text { of the Italian and } \\
\text { Spanish guardians } \\
\text { reported their } \\
\text { youngsters more } \\
\text { fretful, irate, an } \\
\text { touchy. }\end{array}$ & $\begin{array}{l}\text { Online review } \\
\text { with } \\
\text { generalizability of } \\
\text { the research. } \\
\text { Youngsters' } \\
\text { insight was not } \\
\text { taken. } \\
\text { The discrepancy } \\
\text { in rates of events } \\
\text { of emotional } \\
\text { troubles between } \\
\text { children from } \\
\text { various } \\
\text { citizenships could } \\
\text { be a direct result } \\
\text { of various } \\
\text { guidelines of } \\
\text { lockdown and } \\
\text { seriousness of } \\
\text { spread of } \\
\text { Coronavirus. }\end{array}$ \\
\hline
\end{tabular}




\section{Measurement Tools}

Varieties of scale were adopted in the studies $(n=19)$ for assessing the impact of the COVID-19 pandemic on mental health and psychological state among children. The Strengths and Difficulties Questionnaire (SDQ), CoRonavIruS health and Impact Survey (CRISIS) ), Short Mood and Feelings Questionnaire (SMFQ), and Affective Reactivity Index (ARI) were used for measuring children's mental health, mental distress, and existing mood or mood disorder. Brief Resilience Scale (BRS) was used for measuring resilience "an individual's ability to bounce back or recover from stress", while the Impact of Event Scale (IES) was used for measuring psychological responses to trauma. Coping Style Questionnaire (CSQ) or Coping Style Scale (CSS) were used for measuring active/passive coping, and on the other hand, Child Behavior Checklist (CBCL) was used for assessing children's behavior/emotional problems. The scale used in measuring depression, anxiety, stress, and posttraumatic stress disorder were 21-item Depression Anxiety Stress Scale (DASS-21), Revised Child Anxiety and Depression Scale (RCADS), Major Depressive Disorder (MDD), Generalized Anxiety Disorder (GAD), Screen for Child Anxiety Related Emotional Disorders (SCARED), Spence Child Anxiety Scale (SCAS), Child Depression Inventory (CDI), Survey Development Questionnaire, and Child PTSD Symptom Scale for DSM-5 (CPSS-5). Last but not the least, assessing the prevalence of smartphone addiction were used Short Version of Smartphone Addiction Scale (SV-SAS) and Internet Addiction Scale (IAS).

\section{Populaces with More Noteworthy Vulnerable}

Although children are powerless against ecological dangers yet measurements concerning the mental and emotional wellness effect of remaining at home, and social distancing in children as an activity to deal with the COVID-19 spreading are elusive, and not many investigations address this significant angle. Its only 2 studies precisely mentioned that the respondents were started from age 3 and 5 years (Orgilés et al., 2020; Yeasmin et al., 2020). And 1 study was started investigating at age 7 years (Duan et al., 2020), while Mactavish et al., 2020 picked the age at 8 years. However, the data in this review was within the limit of vulnerable age in children who were below 18 years old. There were 6 studies were mentioned that parents where assisted children as respondents and 1 study were targeted the high school students. The total mean age as mentioned 9.08 years (Orgilés et al., 2020), 10.83 years
(Mactavish et al., 2020), 13.9 years ( Ezpeleta et al., 2020), and 15.58 years (Zhang et al., 2020). While there were 2 studies given in percentage $<13$ years with 70.4 \% (Magklara et al., 2020 ), 13 - 18 years with $90.06 \%$ (Duan et al., 2020), and 1 study by Yeasmin et al., 2020 was not specifically noted either mean or percentage age.

\section{Mental Health}

Lockdown in Greece has one of the significant worries of the caregivers was the social disconnection of their children. In numerous nations around the globe children and adolescents have encountered a startling and delayed time of actual disconnection from their companions, peers, educators, more distant family, and different network organizations. Roughly $35.1 \%$ of caregivers reported that the mental well-being of their children was impressively influenced (Magklara et al., 2020). Literature shows that detachment related to isolate measures has negative mental impacts on grownups, including disarray, outrage, and post-awful trouble (Brooks et al., 2020). Dejection may be a significant issue related to social detachment. Forlornness is conceptualized as the contrary feeling of an error between the social contact experienced by an individual and the craving for it (Perlman \& Peplau, 1981). Social separation isn't trailed by dejection. In any case, early proof shows that more than 33\% of adolescents report elevated levels of forlornness, while previous literature review reported that social separation and dejection build the danger of sadness and perhaps tension (Loades etal., 2020).

The SDQ questionnaire in Spain explored that Adolescents had the worst psychological wellbeing during the COVID-19 outbreaks and it was connected to unhealthy activities such as doing online study in a stagnant position, decrease in physical activity, or no physical exercise along with friends as they usually did at the school before the pandemic; an excessive amount of schoolwork or increased screen time (Magklara et al., 2020; Xiang \& Zhang, 2020) as per parents reported were $95 \%$. It brought negative interference, difficulties in sleeping, and changes in body weight as per parents conveyed the changes in significant physiological capacities, for example, eating and sleeping, merit some remark, as they influenced about a $20 \%$ of the example. At the point when children are not at school, for instance at the end of the week or in the special seasons, they will, in general, change their schedules and are normally less genuinely dynamic, they invest more energy on screens, and their rest examples and diets are modified, bringing 
about weight gain (Wang et al., 2020); intensive and frequent of family discussion which made mood changes; worse relationships with others such parents and sibling; and experienced useless nurturing style and it could be as an overburdening to around $40 \%$ parents who helped with the children's homework (Ezpeleta et al., 2020).

Demonstrate that the COVID-19 episode has had a huge psychosocial sway on children. The anxiety rate $(22.28 \%)$ of respondents were in the misery of depressive indications. During the scourge, $29.58 \%$ of respondents announced that they went through over five hours out of each day on the web, which could be a potential danger factor for dependence on the Internet or cell phones (Duan et al., 2020). Studies have demonstrated that smartphone/Internet abuse may prompt mental or conduct issues, causing horrible performance in the examination, diminished genuine social communication, ignoring individual life, relationship problems, and state of mind brokenness (Kahraman \& Demirci, 2018; Soni, Upadhyay \& Jain, 2017). Another finding of Orgilés et al., (2020) reported on their studies that $85.7 \%$ of the parents reported changes in their children's emotional state and behaviors during the COVID-19 pandemic. The most frequent symptom was difficulty concentrating, with $77 \%$ of the parents reporting this symptom. Boredom, irritability, restlessness, nervousness, feelings of loneliness, and being more uneasy and more worried were reported by more than $30 \%$ of parents. As expected, and according to the study of Xie et al., (2020) with Chinese children, the COVID-19 confinement also impacts negatively on the Italian and Spanish children's wellbeing.

It is About $12 \%$ of the Italian and Spanish guardians reported their children as more fretful, irate, and touchy. Staying at home without the opportunity to go outside may build reactions of uneasiness and other related issues, for example, rest issues, actual protests, and stresses and conduct issues that include the family, such as contending with different family members, possibly because the children should be all the more genuinely dynamic. Children got more troubled, and forlorn, perhaps because of the more extended span of the pandemic in Italy contrasted with Spain. True to form, schedules likewise changed during the pandemic for the offspring of the two nations, investing more energy utilizing screens, investing less time doing the actual movement, and dozing more hours. For example, during the isolate, just $14.8 \%$ of the adolescent practice in any event $60 \mathrm{~min}$ of actual movement, as suggested by the
WHO for youngsters somewhere in the range of 5 and 17 years of age, contrasted with before the isolate, when that rate arrived at $54.1 \%$. This finding is likewise following different reflections that caution about the outcomes of children's home restriction, explicitly influencing their mental prosperity as well as their weight status and the danger of expanding screen time (The Lancet Child \& Adolescent Health, 2020).

\section{Emotional Wellness}

Using DASS-21 and found that more than one-fifth of respondents' emotional wellbeing was influenced. The paces of depression indications $(20.9 \%$ for junior school understudies and $29.7 \%$ for secondary school understudies) and anxiety manifestations (25.4\% for middle school understudies and $28.4 \%$ for secondary school understudies) were higher than the rates revealed by late investigations that didn't include any scourge or pandemic (Zhang et al., 2020). For example, an ongoing report was led with an example of 2,679 children matured 10-15 years of age from 25 territories in China, and the outcomes uncovered that the paces of depressive indications are essentially lower in metropolitan zones with $14 \%$ than in-country zones with $23 \%$ (Zhou et al., 2018). Another similar research reviewed 1,597 middle school understudies matured 10-17 years in ShangHai City (a metropolitan territory in China), and the outcomes demonstrated that the paces of anxiety indications and depressive indications were $16.4 \%$ and $17.2 \%$, separately (Liu, Zhang \& Cai, 2017). These results can be utilized to formulate psychological management to improve emotional wellness.

The study in Bangladesh among parents who had children at least age 5-15 years explored that exhibit that huge extents of children are experiencing emotional wellbeing disruption during the lockdown period. Children's emotional wellness (despondency, nervousness, and dozing disorder) scores were ordered into four gatherings: sub-edge, mellow, moderate, and extreme unsettling influence. The most noteworthy level of children are experiencing sub-limit aggravation $(43 \%)$, and $30.5 \%$ had mellow unsettling influences, $19.3 \%$ had moderate aggravations, and $7.2 \%$ had serious aggravations. However, execution of legitimate mental management strategies and improvement in family monetary conditions, parents' education, looking after children appropriately, expanding job stability, and adaptability of parents may help in improving the wellbeing status of children (Yeasmin et al., 2020). The study in Ontario described It distinguishes powerful, expansive mental distress counting diminished prosperity overall records assessed 
and higher irritability, anxiety, and depressive indications after the COVID-19 pandemic. Records wide intense effect on the mental wellbeing of children since that it needs expansive psychosocial supports and assets to assist children with recuperating from the COVID-19 pandemic. Children in the current investigation revealed burdensome and uneasiness manifestations were $25.64 \%$ and $21.52 \%$ which were over a clinically-characteristic edge, individually (Mactavish et al., 2020). Predictable with another study of children in China during the COVID-19 pandemic, in which $22.6 \%$ and $18.9 \%$ revealed raised burdensome and tension indications (Xie et al., 2020).

\section{Limitation}

All studies were conducted utilizing online surveys autonomously by the study respondents, which raises two concerns: (1) individual reactions in self-evaluation shift in objectivity when oversight from an expert specialist/questioner is absent, (2) individuals with helpless web openness were likely excluded from the examination, making a choice predisposition in populace considered. Online studies presented tremendous difficulties for the usage of children as respondents. Online survey with generalizability of the study. Importantly, studies were led in a predetermined number of nations. A greater example size for results approval.

\section{CONCLUSION}

This systematic review proposes that the COVID-19 pandemic is related to an extensive and critical negative impact on emotional wellness and mental prosperity among children. Our study summarized significant and accessible information on children's mental and emotional wellness such as depression, anxiety, feeling lonely, and excessive using screen time during the COVID-19 pandemic. Psychological wellness is a critical concern in a pandemic's situation. Children are viewed as a vulnerable subgroup and there is a need to mitigate the emotional wellness and mental prosperity burden of this pandemic. This investigation can be utilized to figure psychological interventions to improve the emotional wellness and mental prosperity among children during the COVID-19 pandemic.

\section{Conflict of Interest}

The author(s) declared no potential conflicts of interest with respect to the research, authorship and/or publication of this article.

\section{ACKNOWLEDGEMENT}

The authors would like to acknowledge the efforts of the research assistant who helped in the data collection and publishing of this paper.

\section{REFERENCES}

Brooks, S. K., Webster, R. K., Smith, L. E., Woodland, L., Wessely, S., Greenberg, N., \& Rubin, G. J. (2020). The psychological impact of quarantine and how to reduce it: rapid review of the evidence. The Lancet, 395(10227), 912-920. https://doi.org/ 10.1016/S0140-6736(20)30460-8.

Cao, W., Fang, Z., Hou, G., Han, M., Xu, X., Dong, J., \& Zheng, J. (2020). The psychological impact of the COVID-19 epidemic on college students in China. Psychiatry Research, 287, 112934. https://doi.org/ https://doi.org/10.1016/j.psychres.2020.112934.

Duan, L., Shao, X., Wang, Y., Huang, Y., Miao, J., Yang, X., \& Zhu, G. (2020). An investigation of mental health status of children and adolescents in china during the outbreak of COVID-19. Journal of Affective Disorders, 275, 112-118. https://doi. org/https://doi.org/10.1016/j.jad.2020.06.029.

Ezpeleta, L., Navarro, J.B., de la Osa, N., Trepat, E., \& Penelo, E. (2020) Life conditions during COVID19 lockdown and mental health in Spanish adolescents. International Journal of Environmental Research and Public Health, 17(19), 7327.https://doi.org/ 10.3390/ ijerph17197327.

Imran, N., Aamer, I., Sharif, M. I., Bodla, Z. H., \& Naveed, S. (2020). Psychological burden of quarantine in children and adolescents: A rapid systematic review and proposed solutions. Pakistan Journal of Medical Sciences, 36(5), 1106.https:// doi.org/10.12669/pjms .36.5.3088.

Kahraman, O., \& Demirci, E.O. (2018) Internet addiction and attention-deficit-hyperactivity disorder: effects of anxiety, depression, and self-esteem. Pediatrics International, 60(6), 529534.

The Lancet Child \& Adolescent Health. (2020). Pandemic school closures: risks and opportunities. 4(5),341. DOI: 10.1016/S2352-4642(20) 30105-X.

Lee, J. (2020). Mental health effects of school closures during COVID-19. The Lancet Child \& Adolescent Health, 4(6), 421.

Liu, J.J., Bao, Y., Huang, X., Shi, J., \& Lu, L. (2020) Mental health considerations for children 
quarantined because of COVID-19. The Lancet Child \& Adolescent Health, 4(5), 347-349. DOI: 10.1016/S2352-4642(20)30096-1

Liu, Y., Zhang, W., \& Cai, J. (2017). Relation of anxiety and depression to lifestyle in junior high school students. Chinese Mental Health Journal, 31(3), 235-240.

Loades, M. E., Chatburn, E., Higson-Sweeney, N., Reynolds, S., Shafran, R., Brigden, A., ... \& Crawley, E. (2020) Rapid Systematic Review: The Impact of Social Isolation and Loneliness on the Mental Health of Children and Adolescents in the Context of COVID-19. Journal of the American Academy of Child and Adolescent Psychiatry, 59(11), 1218-1239.e3.https://doi.org/10.1016/ j.jaac.2020.05.009.

Mactavish, A., Mastronardi, C., Menna, R., Babb, K.A., Battaglia, M., Amstadter, A. B., \& Rappaport, L. (2020). The Acute Impact of the COVID-19 Pandemic on Children's Mental Health in Southwestern Ontario. Preprint Manuscript, 53(9), $1-31$.

Magklara, K., Lazaratou, H., Barbouni, A., Poulas, K., Farsalinos, K., \& Coronavirus Greece Research Group. (2020). Impact of COVID-19 pandemic and lockdown measures on mental health of children and adolescents in Greece. MedRxiv. 1-16. https://doi. org/https://doi.org/10.1101/2020. 10.18.20214643.

Orgilés, M., Morales, A., Delvecchio, E., Mazzeschi, C., \& Espada, J. P. (2020). Immediate psychological effects of the COVID-19 quarantine in youth from Italy and Spain. Frontiers in Psychology, 11, 2986. https://doi.org/10.2139/ssrn.3588552.

Perlman, D., \& Peplau, L. A. (1981). Toward a social psychology of loneliness. Personal Relationships, 3, 31-56.London:Academic Press.

Pisano, L., Galimi, D., \& Cerniglia, L. (2020). A qualitative report on exploratory data on the possible emotional/behavioral correlates of Covid-19 lockdown in 4-10 years children in Italy. Preprint, page 1-22.https://psyarxiv.com/stwbn/download? format=pdf

Shen, K., Yang, Y., Wang, T., Zhao, D., Jiang, Y., Jin, R., ... \& Gao, L. (2020). Diagnosis, treatment, and prevention of 2019 novel coronavirus infection in children: experts' consensus statement. World Journal of Pediatrics, 16(3), 223-231. https://doi.org/ 10.1007/s12519-020-00343-7.

Soni, R., Upadhyay, R., \& Jain, M. (2017). Prevalence of smart phone addiction, sleep quality and associated behaviour problems in adolescents. International Journal of Research in Medical Sciences, 5(2), 515-519.

UNICEF. (2019). Global population of children 2100. Statista. Retrieved from https://www.statista.com/ statistics/678737/total-number-of-childrenworldwide/ on November 2020.

Wang, G., Zhang, Y., Zhao, J., Zhang, J., \& Jiang, F. (2020). Mitigate the effects of home confinement on children during the COVID-19 outbreak. The Lancet, 395(10228), 945-947.https://doi.org/ 10.3969/j.issn.1674-8115.2020.03.001.

Xiang, M., \& Zhang, Z. (2020) Impact of COVID-19 pandemic on children and adolescents' lifestyle behavior larger than expected too. Progress in Cardiovascular Diseases, 63, 531-532.

Xie, X., Xue, Q., Zhou, Y., Zhu, K., Liu, Q., Zhang, J., \& Song, R. (2020) Mental Health Status Among Children in Home Confinement During the Coronavirus Disease 2019 Outbreak in Hubei Province, China. JAMA Pediatrics, 174(9), 898900.

Yeasmin, S., Banik, R., Hossain, S., Hossain, M. N., Mahumud, R., Salma, N., \& Hossain, M. M. (2020). Impact of COVID-19 pandemic on the mental health of children in Bangladesh: A cross-sectional study. Children and Youth Services Review, 117, 105277.https://doi.org/10.1016/j.childyouth.2020. 105277.

Zhang, C., Ye, M., Fu, Y., Yang, M., Luo, F., Yuan, J., \& Tao, Q. (2020) The Psychological Impact of the COVID-19 Pandemic on Teenagers in China. Journal of Adolescent Health, $\operatorname{xxx}(2020), 1-9$. https://doi.org/10.1016/j.jadohealth.2020.08.026.

Zhou, M., Zhang, G., Rozelle, S., Kenny, K., \& Xue, H. (2018) Depressive symptoms of Chinese children: Prevalence and correlated factors among subgroups. International Journal of Environmental Research and Public Health, 15(2), 283. https://doi.org/ 10.3390/ijerph15020283. 